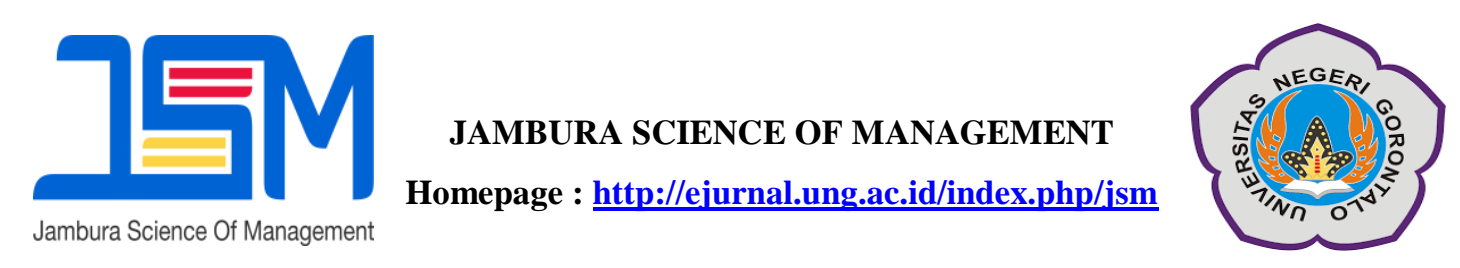

\title{
Testing the Four Factors of the Carhart Model Against Excess Return of Shares in Companies Registered in the Kompas 100 Index for the 2014- 2016 Period
}

\author{
Delvira Mahmud \\ Department of Management, Faculty of Economics, Gorontalo State University \\ E-Mail:Viramahmud@gmail.com
}

\begin{abstract}
:
The researcher intends to test the four carhart factor model of stock excess return in companies incorporated in Kompas 100 for the 2014-2016 period. Regression analysis was performed on four carhart factor models, namely market returns, firm size, book to market, and momentum towards excess return. The results of this study indicate that in the partial hypothesis testing market return, firm size, and book to market equty variables significantly influence the excess return, while the momentum variable does not significantly influence the magnitude of excess return.
\end{abstract}

Keywords: Four factors, market returns, firm size, book to market equity, momentum, excess stock returns

"Don't put all your eggs in one basket" Such is the saying that often underlies investment activities in the capital market in order to avoid the amount of investment risk that might be borne. Investment is a commitment made by humans to a number of funds or other resources to improve welfare and obtain a decent life in the future. Investment can be done by investing in a stock to get a return on investment made by investors (investors). One investment that is quite interesting is the stock investment. The main reason investors invest in stocks is to get maximum profits. Therefore investors must diversify by allocating funds to several companies from different companies. This stock combination is called a stock portfolio. In order for risk to be managed properly, investment must be spread in several securities by forming a portfolio.

At present there are several models that can be used in portfolio formation, namely the Capital Asset Pricing Model (CAPM) model, the Arbitrage Pricing Theory (APT) model, the French Three Factor Model Fama Model, but among the three models there are still deficiencies which cannot capture momentum 
anomalies. Then Jegadeesh and Titman (1993) argue that the momentum anomaly is very important in measuring the rate of return. In response to this condition, Carhart (1997) developed the Fama research and the French Three Factor Model by adding one factor, namely momentum. Carhart (1997) said by adding the fourth factor, namely momentum will reduce error pricing of portfolio returns.

Carhart (1997) notes that a fourfactor model can explain variations in

\section{METHOD}

This study is a reapplication of previous research with differences in the study period used. The population in this study were all companies listed in the compass index 100 for the period 20142016. The sample in this study is the company included in the compass index 100 period August 2014 - January 2016. Companies that are selected are selected using the purposive sampling technique.

\section{RESULTS AND DISCUSSION}

\section{Testing the Regression Model}

The results of testing the regression model obtained obtained F-count value of 50.296 with a significance value of 0.0000 . When compared with the alpha value used which is equal to $5 \%(0.05)$, the significance value obtained is still much smaller so Ho is rejected. Thus it can be concluded that all significant regression coefficients.

1. Testing market returns on excess return portfolio returns based on past returns and consistent with equilibrium market models with four risk factors. Carhart's model considers the Fama and French risk factors, namely market returns, firm size (SMB), book to market ratio (HML), and adds momentum factors WML (Winner Minus Loser) or commonly called UMD (Up Medium Down), PR1YR (priors oneyear momentum).

Based on the results of the analysis that has been done, it is known that the absolute value of $t$-count for the market return variable is 10.735 with a significance value of 0.0000 . This significance value is smaller than alpha value 0.05 so Ho is rejected. Thus it can be concluded that the market return variable has a positive and significant effect on the magnitude of the excess return from the observed portfolio.

2. Testing Firm Size on Excess Return Based on the results of the analysis that has been done, it is known that the absolute value of t-count for the firm size variable is 6.160 with a significance value of 0.0000 . This significance value is smaller than alpha value 0.05 so Ho is rejected. Thus it can be concluded that the firm size variable has a positive and significant effect on the magnitude of the excess return from the observed portfolio.

3. Testing Book to Market Equity on Excess Return

Based on the results of the analysis that has been done, it is known that the 
absolute value of t-count for the book to market equity variable is 4.21 with a significance value of 0.0000 . This significance value is smaller than alpha value 0.05 so Ho is rejected. Thus it can be concluded that the book to market equity variable has a positive and significant effect on the magnitude of the excess return from the observed portfolio.

4. Testing Momentum on Excess Return From the results of the analysis that has been done, it is known that the absolute value of $t$-count for the momentum variable is 1.568 with a significance value of 0.127 . This significance value is greater than the alpha value of 0.05 so that $\mathrm{Ho}$ is accepted. Thus it can be concluded that the momentum factor variable does not significantly influence the magnitude of the excess return from the observed portfolio.

Significance testing on the market return variable on excess return, namely the absolute value of t-count for the market return variable is 10.735 with a significance value of 0.0000 . This significance value is smaller than alpha value 0.01 so Ho is rejected. Thus it can be concluded that the market return variable has a positive and significant effect on the magnitude of the excess return from the observed portfolio. The results of this study are in line with the research of Sharpe (1964),
Lintner (1965), Bello (2008), and Bismark (2009). But this is contrary to the research from Fama (1992) and Tandelilin (2003) which found that market returns or beta if used alone or combined with other variables, he will not be significant to excess return.

Significant testing of the size variable on excess return obtains an absolute value calculated for the firm size variable is 6.160 with a significance value of 0.0000 . This significance value is smaller than alpha value 0.01 so Ho is rejected. Thus the firm size variable has a positive and significant effect on the magnitude of the excess return from the observed portfolio. The results of this study are different from those of Banz (1981) and Fama (1992) who found a negative relationship between company size and stock returns. The results of this study are also different from the results of Glenny \& William's study, which obtained a size \& momentum variable that did not affect the excess retention.

The results of the significance of the book to market variable on the excess return obtain the absolute value of t-count for the book to market equity variable is 4.21 with a significance 
value of 0.0000 . This significance value is smaller than alpha value 0.01 so $\mathrm{Ho}$ is rejected. Thus at the $99 \%$ confidence level it can be concluded that the book to market equity variable has a positive and significant effect on the magnitude of the excess return from the observed portfolio. The results of this study are consistent with Fama (1992) and Statman (1980) who found a positive relationship to book to market with stock returns.

Whereas for testing the significance of momentum obtaining the absolute value calculated for the momentum factor variable is 1.568 with a significance value of 0.127 . This significance value is greater than alpha value 0.01 so $\mathrm{Ho}$ is accepted. Thus at the $99 \%$ confidence level it can be concluded that the momentum variable is a factor that does not significantly influence the magnitude of the observed excess return from the portfolio. The results of this study are different from the results of Pramusinta \& Arfianto's research which found that momentum variables have a positive and significant effect on stock returns.

\section{CONCLUSION}

Based on the results of data analysis and discussion of the effect of the four carhart factor models on excess return, the following conclusions can be drawn:

1. Market returns have a significant positive effect on stock excess returns in all portfolios formed in this study.

2. Size variables measured by market capitalization have a positive and significant effect on stock excess returns

3. Book to market variable (HML) has a positive effect on excess return.

4. The momentum variable does not have a significant effect on excess return.

\section{REFERENCES}

Arifin, Zaenal. 2005. Teori Keuangan \& Pasar Modal. Yogyakarta : Ekonisla

Candika, Iman Yossy. 2017. Pengujian Kekuatan Model Carhart Empat Faktor Terhadap Excess Return Saham Di Indonesia. The Indonesian Journal Of Applied Business. Volume 1 Nomor 1

Czapkiewz, Anna \& Tomasz Wojtowicz.

2014. The Four Factor Asset Pricing Model On The Polish Stock Market. Economic Reserach- Ekonomska Istrazivanja. Volume 27, No.1, Halaman 771-783

Gleny \& William Tjong. 2014. Pengaruh Strategi Value, Size Dan Momentum Terhadap Excess Return Di Indonesia. Jurnal Sosial Humaniora. Volume 7 No.2 Halaman 172-188 
Husni, Tafdi. 2006. Momentum Strategies And Trading Volume Turnover In Malaysian Stock Exchange. Jurnal Widya Manajemen \& Akuntansi. Vol. 6 No.1 Hal: 42 51

Kampman, Tijmen. 2011. Explaining Stock Returns : The CAPM, Fama-French Three Factor Model And Carhart's Four Factor Model. Journal Of Management

Lopez, Humberto Levarhty. 2014. On The Robustness Of The Capm, FamaFrench Three Factor Model And The Carhart Four-Factor Model On The Dutch Stock Market. Bachelor Thesis In Finance Mardiyah, Ainul Aida. 2002. The Effect Of Profitability of Momentum Strategies And Volume On Future Returns : An Emprical Evidence From Jakarta Stock Exchange And Kuala Lumpur Stock Exchange. Jurnal Ekonomi Dan Bisnis Indonesia. Volume 7 Nomor 4 Halaman 440-459

Mwalla, Mona Al. 2010. Can Book-toMarket, Size and Momentum be Extra Risk Factors that Explain the Stocks Rate Of Return?: Evidence from Emerging Market . Journal of Finance, Accounting and Management, 3(2): 42-57 Nugroho, Yuliarto B. 2008. Profitabilitas Strategi Momentum Di Bursa Efek Indonesia (Periode Januari 2003-Desember
2007). Jurnal Siasat Bisnis Volume 12 No.3 Hal. 175-186

Olbrys, Joanna. 2011. Book To Market, Size, And Momentum Factors In Market Timing Models The Case Of The Polish Emerging Market. Research In Economics And Business : Central And Eastern europe. Vol. 3 No. 2

Tai, Chu-Sheng. 2003. Are Fama - French and Momentum Factors Really Priced?. Journal of Multinational Financial Management 13: 359384

Tandelilin, Eduardus. 2010. Portofolio dan Investasi; Teori dan Aplikasi. Yogyakarta: Penerbit Kanisius. 